IZA DP No. 8167

A Survey of the Economics of Fair Trade

Ana C. Dammert

Sarah Mohan

May 2014

Forschungsinstitut

zur Zukunft der Arbeit

Institute for the Study

of Labor 


\title{
A Survey of the Economics of Fair Trade
}

\author{
Ana C. Dammert \\ Carleton University \\ and IZA \\ Sarah Mohan \\ Carleton University
}

\section{Discussion Paper No. 8167 \\ May 2014}

\author{
IZA \\ P.O. Box 7240 \\ 53072 Bonn \\ Germany \\ Phone: +49-228-3894-0 \\ Fax: +49-228-3894-180 \\ E-mail: iza@iza.org
}

Any opinions expressed here are those of the author(s) and not those of IZA. Research published in this series may include views on policy, but the institute itself takes no institutional policy positions. The IZA research network is committed to the IZA Guiding Principles of Research Integrity.

The Institute for the Study of Labor (IZA) in Bonn is a local and virtual international research center and a place of communication between science, politics and business. IZA is an independent nonprofit organization supported by Deutsche Post Foundation. The center is associated with the University of Bonn and offers a stimulating research environment through its international network, workshops and conferences, data service, project support, research visits and doctoral program. IZA engages in (i) original and internationally competitive research in all fields of labor economics, (ii) development of policy concepts, and (iii) dissemination of research results and concepts to the interested public.

IZA Discussion Papers often represent preliminary work and are circulated to encourage discussion. Citation of such a paper should account for its provisional character. A revised version may be available directly from the author. 


\section{ABSTRACT}

\section{A Survey of the Economics of Fair Trade ${ }^{*}$}

Fair Trade has spread in developing countries as an initiative aimed at lifting poor smallholder farmers out of poverty by providing them with premium prices, availability of credit, and improved community development and social goods. Fair Trade is also viewed as a niche market for high value products in a context of globalization and trade liberalization policies that affect smallholder farmers in developing countries. The question of whether Fair Trade affects the welfare of rural farmers, however, is particularly contentious. This paper provides a review of the Fair Trade literature, both theoretical and empirical, with a specific focus on the analysis of small-scale producer's welfare in developing countries. Our review shows that while most empirical papers have focused on the impacts of Fair Trade on prices and income, our review highlights the importance of limited market access and changes in productivity. Likewise, little is known about the impacts of Fair Trade on labor markets and human capital investments. Persistent methodological challenges make it challenging, however, to assess the causal impact of this certification and labelling initiative.

JEL Classification: O19, P46

Keywords: $\quad$ Fair Trade, developing countries, market efficiency

Corresponding author:

Ana C. Dammert

Carleton University

Department of Economics

B-846 Loeb Building

Ottawa, ON, K1S 5B6

Canada

E-mail: ana_dammert@carleton.ca

\footnotetext{
* This research has benefited from comments and suggestions received by two anonymous referees. Ana C. Dammert gratefully acknowledges financial support from the Social Sciences and Humanities Research Council of Canada (SSHRC). Any errors and omissions are our own.
} 


\section{Introduction}

During the last twenty years, a burgeoning literature has accompanied the rise of Fair Trade certification. As Fair Trade coffee sales have increased to capture as much as 10 percent of the specialty coffee market in the US and world shops have become common in many capitals, the claims made by Fair Trade schemes have come under increased scrutiny. This survey will focus on one important aspect of Fair Trade, namely whether producers in developing countries have improved their welfare by participating in Fair Trade markets. ${ }^{\mathrm{i}}$

Although unlabeled Fair Trade products have been sold in specialized shops in the US and Europe since the end of World War II, the origins of labelled forms of Fair Trade can be dated to the late 1980s, when the Max Havelaar Foundation launched the first Fair Trade coffee label. By the end of the 1990s, 17 Fair Trade label initiatives had been introduced, which joined together to create the Labelling Organizations International (FLO). The main objective of FLO is to "contribute to sustainable development by offering better trading conditions to, and secure the rights of, marginalized producers and workers - especially in the South” (FINE 2001).

Producers have to meet a variety of criteria that focus on a range of areas, including labor standards, sustainable farming, governance, and democratic participation (FLO 2010). Certified groups are guaranteed a minimum price for their produce, which is defined according to product and region. If the market price is above the minimum price, Fair Trade contracts must pay at least as much as the market price. Groups are paid a social premium amount in addition to the market price, which is mandated for community social, health, and infrastructure investments. Contracts are guaranteed for many seasons to reduce fluctuations in market access and price. For most products, only co-operatives of farmers can be Fair Trade certified. In cases of plantation 
crops, such as cotton or tea, the plantation itself can be certified, with corresponding rules for the treatment of labor.

Over the past decade, the number of FLO-registered producer organizations has grown rapidly, from 508 in 2005 to 991 at the end of 2011. The majority of Fair Trade-certified organizations are located in Latin America and the Caribbean; indeed, 9.18 and 8.27 percent of all certified organizations are located in Peru and Colombia, respectively. Coffee growers' organizations are the largest product group, accounting for about $35 \%$ of all registered producer organizations, but other products are expanding as well, including sugar and tea (FLO 2012).

Fair Trade certification is carried out by FLO-Cert, which was created by Fairtrade International in 2004. Producer organizations must pay the application, initial certification fee, and renewal fees. The yearly certification fee ranges from 1,430 Euros for an organization with less than 50 members to 3,470 Euros for an organization with more than 1,000 members (FLOCert 2011). There are also costs associated with paying for inspection and renewal of certification (Geiger-Oneto and Arnould 2011), hiring a cooperative marketing manager (Bezencon 2011), as well as paying down debts associated with periods during which the cooperative was certified but was unable to find an overseas buyer (Geiger-Oneto and Arnould 2011).

Do the contractual modalities and the empirical realities of certification actually support the goals of Fair Trade schemes? In particular, what is the impact of Fair Trade on the welfare of small-scale producers in developing countries? This paper aims to answer these questions by reviewing dozens of theoretical and empirical studies on different countries ${ }^{\mathrm{ii}}$. A growing body of work summarizes the effects of Fair Trade certification, but with minimal indication of the methodological issues and the potential effects of selection bias. For example, the study by 
Nelson and Pound (2009) synthesized the findings from 33 case studies regarding the impact of Fair Trade on income, environment, gender, and producer empowerment. Vagneron and Roquigny (2010) study synthesized the findings from 77 case studies on Fair Trade certification impacts on several economic outcomes. Both studies provide strong evidence regarding the positive impacts of Fair Trade, mostly on prices and farmers' income, but most of the reviewed work relies on mean comparisons between different categories of farmers without controlling for the various factors that can determine Fair Trade certification.

Taking into consideration the methodological challenges raised by taking mean comparisons, Blackman and Rivera (2011) selected peer-reviewed publications or books published by third parties before 2010 that provide an ex-post impact analysis of Fair Trade certification in different crops. In the coffee sector, the authors synthesize 20 case studies and found that these case studies provide more modest evidence that Fair Trade has positive impacts on social, environmental, and economic outcomes. Similarly, the review by Dragusanu, Giovannucci, and Nunn (2013) shows that Fair Trade and organic certification is correlated with more environmentally friendly farming practices and the perception that the economic environment is more stable. More research is needed in order to unveil the causal impacts of Fair Trade certification.

We contribute to the existing literature by reviewing the theoretical work to date on Fair Trade, and through our study of both empirical papers that statistically control for differences among Fair Trade and non-Fair Trade producers and those that do not control for those differences. Our survey of empirical papers will focus on Fair Trade coffee given the large share of certified producer organizations that make this product and since most empirical evidence focuses on coffee. 
Our review shows that most empirical papers have focused on the impacts of Fair Trade certification on prices and income. This is not surprising, given that one of the main premises of Fair Trade is the establishment of price floors. Cross-sectional papers that rely on simple mean comparisons find significant price differences, while papers that account for selection bias find modest price differences. It is important to note that a significant amount of heterogeneity exists surrounding how prices and income are defined. Conversely, little is known about the impacts of Fair Trade on human capital investments and labor markets. Due to the income effect derived from Fair Trade certification, we may observe some changes in health and education outcomes of those directly benefiting from it. Likewise, hired labor in the production of the certified crop is regulated by the FLO; for example, cooperatives of small-scale producers are eligible to obtain Fair Trade coffee certification if farm work is mostly performed by family members. Overall, more research is needed on the impact of Fair Trade certification given the expansion and potential role of Fair Trade certification in the improvement of the livelihood of small-scale farmers and workers in developing countries.

The rest of the paper is structured as follows. The next section examines economic theories of Fair Trade, while section three discusses methodologies that have been used for assessing the welfare impact of Fair Trade. This includes how and what data is gathered, how outcome variables are defined, and the econometric methodologies used to analyze data. Section four presents the findings from the literature on welfare indicators, including net income, price, output, and access to credit. The last section highlights key insights as well as research gaps and concludes. 


\section{The Economics of Fair Trade}

The question of how Fair Trade affects the welfare of small-scale rural farmers is a contentious one. From a theoretical point of view, one of the most controversial issues within this topic is the price premium. In particular, Fair Trade has been assessed regarding the potential effects of using price floors as a mechanism to increase local producers' incomes. The price premium may hamper general equilibrium market clearing and create excess supply and inefficiencies by distorting market mechanisms. If Fair Trade is sufficiently large to impact world markets, demand for mainstream non-Fair Trade products could be reduced as consumers begin buying Fair Trade products, thus generating a negative demand externality. At the same time, world supply could be affected as some producers move out of the mainstream market to produce for the Fair Trade market. If the reduction in demand is bigger than the reduction in supply, many producers will be selling to a smaller market, and mainstream producers could be made worse off depending on the price elasticity of demand (Leclair 2002). If supply is large relative to demand, prices will tend to decrease.

If demand is elastic, more people will buy the cheaper good and the incomes of mainstream producers will increase. If demand is inelastic, the same number of people will buy the good and incomes will decrease given the lower price (Hayes 2008). If the extent of the global market is reduced, mainstream producers may be forced to focus on local markets. If Fair Trade and mainstream producers are both selling at least in part in local markets, Fair Trade producers may cross-subsidize their production and undersell mainstream producers (Maseland and De Vaal 2009).

Some authors, however, argue that the price premium is justifiable due to its potential to eradicate monopsony powers and other market imperfections in supply chains. In linked input 
markets, where market power is yielded to increase the cost of fertilizers, credit, or access to infrastructure, Fair Trade could restore competition and reduce input prices. According to Hayes' model of a Pigou-Robinson employer monopsony, the employer buys the harvest from the smallscale farmer or craftsperson or employs them in production. In this context, Fair Trade is viewed as an alternative to employer monopsony for independent producer households or other workers. While this yields welfare benefits independent of the price premium, if the Fair Trade cooperative is too small to affect the monopsonistic employer, the price premium is required to obtain pro-competitive effects (Hayes 2006). When imperfect competition is in place with a monopsonistic/oligopolistic market structure, prices may not be Pareto-optimal; instead, they may reflect the market power of exporters, importers, or intermediaries. For example, Ronchi (2006) finds that downstream actors exercise market power in the coffee sector in Costa Rica which reduces the amount farmers get paid. The author finds that Fair Trade organizing enables farmers to improve their market power, resulting in better prices.

Moreover, when there are transaction costs, such as from acquiring information about market requirements, transporting goods, and acquiring bargaining power with other actors, Fair Trade can help underprivileged market actors pay for such costs. For example, some producers may encounter search frictions in finding an importer willing to buy their products. In the presence of these market failures, the Fair Trade scheme may subsidize co-operatives' efforts to match with an importer and improve their bargaining power (Baumann et al. 2012).

Economists have also modeled how Fair Trade schemes affect the quality of the product sold. In De Janvry et al's model (2011), rents from Fair Trade are dissipated through quality arbitrage where conventional markets reward quality, but Fair Trade markets do so only weakly. The best-quality product will sell on premium conventional markets, the Fair Trade price will 
garner medium-quality coffee, and low-quality product will sell at the basic price. Alternatively, Richardson and Stahler (2007) present a model of two quality-differentiated oligopolistic markets, where Fair Trade operates in one, and in which there is a moral hazard problem incentivizing the use of poor-quality inputs.

Although rarely mentioned in the theoretical literature, access to developed-country markets is one of the primary reasons that small-scale producers seek out Fair Trade certification. However, De Janvry et al (2011) show that despite farmers incurring costs for higher-quality, certified production for their produce, they may sell only a small percentage of their output to Fair Trade channels. The percentage of Fair Trade certified sales in total cooperative sales can range from 13 to 100\%, with an average of around 30\% (de Janvry et al 2011). Farmers only earn premium prices on the percentage sold as Fair Trade, although all of the produce is certified as Fair Trade. The phenomenon of limited actual Fair Trade sales cuts into the financial benefits of Fair Trade for farmers. In the model by Janvry et al, overcertification also reduces rents from certification since Fair Trade provides a demand channel with open access at a fixed cost, yet it does not provide a commitment to buying all output. Thus, farmers pay the cost to acquire Fair Trade certification and only enter the market as long as it is profitable to do so. As many organizations become certified, however, given limited demand, the percentage of each organization's sales to Fair Trade is reduced. Potential entrants find the cost of certification to be higher than the returns they would make from the Fair Trade premium earned on a limited percentage of their product.

Fair Trade has also been assessed regarding its potential effects on labor markets. If there is low labor demand in rural areas, then the household production possibility set may include a range of activities that yield less than the market wage, but offer more than the marginal utility of 
leisure. The introduction of Fair Trade production increases opportunities for employment at market wages and with higher levels of productivity, thereby enabling farming households to move away from activities in the interior of their production possibilities set to a point closer to the frontier (Hayes 2006). Wages may go up throughout a region in response to higher Fair Trade wages (Ruben et al. 2009), and the Fair Trade social premium's investment in health, education, and infrastructure can benefit all actors in the economy.

Finally, it has been questioned whether Fair Trade price premiums are the best way to support underprivileged small-scale producers. Leclair (2002) notes that it may be more efficient for consumers to give grants to development aid organizations that provide direct help to underprivileged producers, since the Fair Trade premium's welfare benefits may be diffused by income effects which will tend to reduce farmers' effort and the quantity of products sold, thereby reducing the amount of the premium received by the farmer. Despite this potential drawback, the same author concludes that Fair Trade may nonetheless be preferable, "primarily because it allows work, rather than passive acceptance of aid, to be a means of improving standards of living" (Leclair 2008: 2962). Other analysis suggests that Fair Trade is not necessarily inefficient and that there may be general equilibrium effects; for example consumers also gain a personal benefit from the knowledge that they are giving their money directly to the person who is growing their coffee, known as the "warm glow effect" (Hayes 2008, Richardson and Stahler 2007). 


\section{Methodological Issues}

Establishing the impacts of Fair Trade certification on households is not a straightforward task. The problem lies in the fact that we cannot observe directly from the data what would have happened had farmers not participated in Fair Trade (counterfactual data). Empirically, we observe separately the outcomes of those who are affiliated with Fair Trade and the outcomes of those who are not affiliated with Fair Trade. After a simple estimation of the mean difference in outcomes between these two groups, the estimates are likely to be affected by selection bias, given that the certification decision might be driven by unobserved factors (e.g. motivation) or observed factors.

Fair Trade certification begins with producers, usually associations of small-scale farmers or firms who make the raw ingredients in Fair Trade-certified products. In the case of cooperative certification, in most cases the cooperative existed prior to seeking out Fair Trade certification, such as for the purpose of government extension or to obtain organic certification. Depending on the particular cooperative, farmer members may each pay a portion of the costs of certification or the cooperative itself can pay them using the organizations' savings and/or other revenue sources. While the practice varies from case to case, most cooperatives have procedures in place to allow in new members, govern themselves, and provide technical assistance to their members (Raynolds et al 2004).

The study of the determinants of selection into certification is an understudied aspect of Fair Trade. If the producers with the highest productivity bear the costs of adapting new standards of production and becoming part of a cooperative, then there might be positive selection into Fair Trade (Breimer and de Vaal 2011). Given the targeting of small and disadvantaged farmers, there is some evidence of negative selection into Fair Trade. For 
example, Fort and Ruben (2009b) conducted a study of 360 Peruvian coffee farmers in three organizations and showed that Fair Trade-certified farmers have less education and own smaller farms than non-certified farmers. Similarly, Saenz-Segura and Zuniga-Arias (2009) show that, within a sample of 103 Fair Trade-certified coffee producers in Costa Rica organized in nine cooperatives, Fair Trade producers have only primary education and possess less experience than non-certified ones.

Papers that analyze cross-sectional or time series data control for selection bias through a two-stage participation-treatment model (Weber 2011; Becchetti et al. 2011), fixed effects (Barham and Weber 2012), and stratified cluster sampling and factor analysis (Geiger-Oneto and Arnould 2011). Other studies compared sample means between treatment and non-treatment groups using ANOVA or nonparametric difference tests, however, without controlling for differences between the two groups (Arnould et al. 2009; Beuchelt and Zeller 2011; Jaffee 2009). If there is negative selection into Fair Trade, as some of the empirical papers suggest, these estimates are biased downward and thus understate the effects of Fair Trade.

Based on the evaluation literature, different approaches have been used to construct a credible counterfactual. One approach would involve the randomization of farmers into Fair Trade (treatment) and non-Fair Trade (control) groups. Randomization ensures that all observable (e.g. education, age, farm size) and unobservable characteristics (e.g. motivation) are the same for both groups. In the context of Fair Trade, however, the random assignment of farmers is highly unlikely in light of its institutional and political features. In the absence of a randomized assignment, a common approach used to correct for potential selection bias is propensity score matching. In this case, certified producers are paired with uncertified producers that have very similar, if not identical, observable characteristics that plausibly affect outcomes. 
Several studies used this approach, including manual field-based matching and propensity score matching (Fort and Ruben 2009a; Fort and Ruben 2009b; Zuniga-Arias and Saenz-Segura 2009; Saenz-Segura and Zuniga-Arias 2009; Ruben and van Schendel 2009; Ruben and Zuniga 2011). It should be noted that propensity score matching estimates are still biased if there are important unobserved differences between the groups.

\section{Outcomes of Interest}

Most papers that focused solely on price paid to the cooperative as the dependent variable found a positive impact of Fair Trade on that outcome. However, price is a very weak indicator of producer welfare. Fair Trade certification involves associated costs and changes in productivity. Several studies defined price based on the internationally defined Fair Trade minimum price and assumed that this price was received by producers. However, the minimum price is not generally equal to the farm-gate price received by Fair Trade farmers. Cooperatives receive the minimum price, and they often take deductions, for example to compensate for export credit costs or to pay down debt incurred to obtain certification (Calo and Wise 2005). There is evidence suggesting that the certification cost is significant for small cooperatives; Saenz-Segura and Zuniga-Arias (2009) report that one-third of the total Fair Trade premium received was used to pay for certification in a Fair Trade coffee cooperative in Costa Rica. Although the weight of the evidence suggests that Fair Trade production is more costly than non-Fair Trade production (Fort and Ruben 2009a; Zuniga-Arias and Saenz-Segura 2009; Smith and Loker 2012; Ruben and Zuniga 2011), evidence on actual costs is scant due to difficulty in obtaining data, particularly comparable field-level cost data. If there are barriers to entry, in the form of significant certification costs, the poor could be excluded from participating in Fair Trade. 
Furthermore, when cooperatives obtain a Fair Trade price on only a fraction of their sales, as is often the case, they apply cooperative rules to distribute a portion of the premium amount to all farmers. For example, some cooperatives divide the total premium cash received from Fair Trade sales across the total quantity of product purchased from farmers and then distribute this amount in proportion to the amount of product sold by each farmer (de Janvry et al 2011). Calculations that are based on co-operative price records will record this price. However, farmers sometimes sell part of their crop outside the Fair Trade co-operative to local intermediaries, especially during the lean season, when immediate cash is needed (Valkila and Nygren 2010). Calculations based on prices reported by farmers throughout the year will record a true farm-gate price based on a weighted sum of the prices received from different sales outlets. Finally, quality can vary throughout the year, and whether the price paid is a premium for quality or for Fair Trade can commensurately change, although this effect is only rarely controlled for (Barham et al 2011; de Janvry et al 2011).

Similarly, studies that define the income of producers as the outcome variable are also methodologically problematic. If revenues are defined as prices multiplied by quantity, then the concerns regarding price measurement described in previous paragraphs are relevant. Quantity can be defined through reference to cooperative records, by farmers' reported sales to the Fair Trade cooperative, by farmers' total reported sales, by farmers' reported total yields (including household consumption), or by measured yields. Each measure yields a different scale of impact.

With regards to net income, some studies do not subtract any costs before reporting revenue statistics while others do deduct such costs and report on net income. Weber (2011) defines the "net premium" from Fair Trade-organic sales as the Fair Trade-organic mandated price minus the per-unit certification cost (including certification fees and building 
infrastructure). The author notes that this equation takes into account neither farm-level costs nor pecuniary benefits from social premium spending. Beuchelt and Zeller (2011) define economic profit as the accounting profit minus opportunity costs such as interest for machines and variable cost, opportunity cost of land, and opportunity cost of family labor, where the interest rate used is $17 \%$ as is common in the region. Calo and Wise (2005) deduce producer cost as certification cost/area plus organization costs subtracted from actual producer prices along with presumed labor cost/quintal (which is different for organic and conventional farmers) to find net income. Valkila (2009) accounted for field-based fertilizer and yield use. Still others simply state the changes in income, costs, and profit without reporting how these amounts were calculated.

There are thus methodological issues in defining the dependent variable in Fair Trade impact studies. No studies used data on net income/profits of Fair Trade and non-Fair Trade producers based on detailed field-level information about yields, labor costs, fertilizer costs, opportunity costs, per-farmer certification costs, and average received price. Few examine the changes in household-level costs, notwithstanding evidence that Fair Trade production functions are significantly different from conventional ones (Ruben et al. 2009). While certification can involve intensification of production, with more inputs and outputs, sometimes it involves reduction in input use, for example when undertaken with organic production in regions with pre-existing industrial agriculture practices and this is rarely discussed (see Valkila 2009 for an exception).

\section{Findings}

\section{IV.1 Prices}

The main characteristics of the Fair Trade movement are associated with the Fair Trade premium and price floors. ${ }^{\mathrm{iii}}$ Thus, it is not surprising that most cross-sectional studies find that 
the price received by Fair Trade certified producers is significantly higher than the price received by non-Fair Trade producers. For example, within a sample of 469 coffee producers in Central America and Mexico for the 2003/2004 harvest, Mendez et al. (2010) construct an average price measure using farm gate prices received from different markets (organic, certified Fair Trade, and conventional) weighted by the percentage of the harvest sold at that price to reflect the prices that farmers obtain at the farm gate. The authors find that Fair Trade certified farmers received \$0.17 more per pound of coffee sold while Fair Trade/Organic certified farmers received \$0.38 more per pound of coffee sold compared to non-certified farmers.

When the Fair Trade prices paid to the cooperative are taken as the farmer's received price without taking into account that there may be averaging across all sales by the cooperative before pay is given to farmers, the positive price differential for Fair Trade sales is still present. Bacon (2005) study of 228 Nicaraguan farmers in the 2004 growing season found that the average prices received at the farm gate were $\$ 0.84$ per pound for Fair Trade coffee, $\$ 0.63$ per pound for Organic coffee, and \$0.41 per pound for conventional coffee. Given that farmers do not sell their entire crop as certified and the average price received is lower, certified farmers selling at least in part to Fair Trade/Organic markets received an average price of $\$ 0.56$ per pound. Similarly, Arnould et al. (2009) found that farmers who were Fair Trade certified received higher prices per pound of coffee sold in a study of 1,269 coffee farmers from Peru, Nicaragua, and Guatemala in the harvest of 2004/2005.

It should be noted that the producer organization is paid the set Fair Trade minimum price for coffee, which is unaffected by fluctuations in world price. Farmers are guaranteed to receive the floor price when international coffee prices are lower than the minimum price; otherwise, farmers receive the international price. Most cross-sectional studies on coffee refer to 
the harvest between 2000 and 2005-2006 during which international coffee prices were relatively low, which may lead to stronger Fair Trade price differences (Ruben 2009). An alternative strategy is to follow producers over time in order to capture fluctuations in world prices. For example, Dragusanu and Nunn (2013) analyzed six coffee cooperatives from Costa Rica between 1999 and 2010 and found a significant but moderate price differential between Fair Tradecertified farmers and conventional farmers of about $\$ 0.04$ per pound on average. Given the lack of data, however, longitudinal evidence is scant.

One of the shortcomings of the previous literature, as mentioned before, is that most studies compare outcomes of Fair Trade certified farmers against farmers delivering to the conventional market, but these two groups are not really comparable if there is selection into Fair Trade. For example, if selection into Fair Trade is correlated with characteristics that also cause farmers to produce better quality coffee and thus charge a higher price, the price difference may be upward biased. Thus, the previous findings are informative but should be taken with caution.

An alternative strategy is to use propensity score matching in order to reduce the bias in the estimates. For example, Fort and Ruben (2009b) use propensity score matching to pair Fair Trade certified producers with similar non-certified producers based on observable characteristics such as age, family size, farm tenure, and farm size, among others. The main results for 360 coffee farmers from Fair Trade certified cooperatives and matched non-certified cooperatives in Peru suggest no evidence on price differentials. The authors explain the absence of a price difference amongst coffee producers by the small proportion of sales made to Fair Trade markets and by the cooperative practice of paying producers the average price of the different markets where it is sold. 


\section{IV.2 Productivity}

Fair Trade certification often goes hand in hand with the establishment of a cooperative and other certification schemes which may affect productivity. Many papers suggest that Fair Trade and/or Organic certified cooperatives help farmers innovate more, including through capacity-building in farming techniques that enable farmers to experiment with ways to improve productivity, quality, and reduce costs: indeed, some suggest this is a primary way that Fair Trade benefits the poor (Hayes 2008; Raynolds et al 2004; Blackmore et al 2012). This is consistent with information economics theory, since the cooperative may enable farmers to acquire information on downstream demand, learn technologies of production, and through certification eliminate moral hazard problems associated with excess chemical use and poorquality produce.

It should be noted that evidence on the impact of Fair Trade certification on yield intersects with the changes in the intensity of production and the uptake of Organic practices. Indeed, according to FLO (2012), about 61 percent of all Fair Trade-certified small producer organizations reported holding Organic certification in 2011. Valkila (2009) points out that there is a continuum of farming practices from those that are low-input and low-yield to those that are high-input and high-yield. If Fair Trade and Organic standards are adopted in low-input, lowyield environments, certification can increase income by increasing price and perhaps marginally increasing yield by adopting explicit organic fertilization practices. With medium- or highintensity management, advantages are less clear. Many cooperatives undergo both certifications, given that much of the world demand for Fair Trade products requires that it be also Organic. Moving from high-intensity management using chemical fertilizers and pesticides to Organic production could adversely affect productivity (Barham et al 2010). 
Cross-sectional mean difference studies provide mixed evidence. Based on total volume, the study by Arnould et al. (2009) of 1,269 farmers from Nicaragua, Peru, and Guatemala show that Fair Trade certified farmers sell more coffee than non-certified farmers. Similarly, Mendez et al. (2010) conducted a study of 469 coffee producers in Central America and Mexico and found that Fair Trade- or Organic-certified farmers produced more than either farmers holding either certifications or non-certified farmers. Measuring productivity as yield per hectare, Beuchelt and Zeller (2011) estimated that there is not much difference between conventional and Organic/Fair Trade output among 327 cooperative members in Nicaragua.

The diversity of results might be driven by how productivity is defined, but all rely on simple mean comparisons without controlling for the various factors that affect farmers' performance. Differences between Organic, Fair Trade, and conventional growers could reflect local conditions or pre-existing differences in management techniques that increase yields. Of the empirical papers that aimed at controlling for selection bias, the evidence suggests that yields may be at least as important as prices, if not more so, in changing the profits that producers make. The study by Barham et al. (2011) of 845 coffee growing households in Southern Mexico defined net income as total revenue (price times sales) minus cash costs and revealed that yield differences account for at least two-thirds of the difference in the net revenue per hectare gap between Fair Trade-Organic and conventional producers.

\section{IV.3 Income}

Another debatable issue is the income effect of Fair Trade certification. Most early studies found a clear, positive, and significant correlation (Jaffee 2009; Ronchi 2002). However, as noted in the methodology section, these estimates may be affected by selection bias. In 
addition, there is great variety in the measures reported as "net income" or "profit". In most cases, a gross revenue statistic is calculated using factory- or farmer-reported prices and output. Costs are subtracted from this figure, including for example time spent on cooperative participation, per-farmer certification costs, opportunity costs at market interest rates, cash expenses, and household labor time. Most reported net income statistics refer to net income from sales of the product that is Fair Trade certified only, and most are reported at a household level, not on a per-capita basis.

Studies that control for selection bias find that the extent of predicted income gains from conversion to Fair Trade is small relative to the gains reported in the literature on other incomegenerating initiatives such as migration or employment in the rural non-farm economy. For example, a study by Weber (2011) of 845 coffee growers in the states of Oaxaca and Chiapas in Mexico show that income gains from Fair Trade are approximately 5\% of household income net of the cost of cooperative participation but before other costs are subtracted.

It should be noted that, in a context of limited net income gains, Fair Trade certification may still have an effect on household welfare, since the Fair Trade premium retained by the cooperative is meant to be invested in social projects. The empirical literature has reported issues with the governance of the social premium, however, particularly in being spent on the cooperative's normal business costs (Valkila and Nygren 2010), distribution by a plantation owner to curry favor (Makita 2012), contestation of plantation Joint body funds (Riisgaard 2009; Blowfield and Dolan 2010), and limited benefits to farmers from the social premium (Fort and Ruben 2009b; Zuniga-Arias and Saenz-Segura 2009). Makita (2012) suggests that the administration of the social premium should be delegated to an independent third party to improve the likelihood of benefits for producers and workers. Even though these findings are 
informative, more research is needed in regards to the decision-making process and efficiency gains of investments of the Social Premium.

\section{IV.4 Market Access and Financial Assets}

Cross-sectional mean difference studies show that Fair Trade producers have more access to credit or savings compared to non-Fair Trade producers. For example, in a study by Mendez et al. (2010) of 469 coffee producers in Central America and Mexico, Fair Trade farmers had higher reported access to credit (42\%) than conventional coffee farmers $(34 \%)$. This could be related to the fact that the Fair Trade social premium finances "credit funds" that are run by cooperatives to make credit available to producers (Ronchi 2002; Ruben et al 2009). These funds are particularly useful insofar as banks often fail to provide credit to small-scale producers (Utting-Chamorro 2005), despite the need for access to working capital for financing investments (Farnworth et al 2006; Nelson and Pound 2009). Although the available data is limited, Fair Trade cooperatives appear to charge at least as much as or more than private companies. For instance, anecdotal evidence suggests that private companies provided free shortterm loans during the growing season in Nicaragua, while Fair Trade cooperatives charged an $18 \%$ interest rate on their loans (Valkila 2009).

There is also suggestive evidence on savings and assets. Geiger-Oneto and Arnould (2011) found that, among 1,269 coffee producers in Guatemala, Nicaragua, and Peru, more Fair Trade coffee producers opened savings accounts over a three-year period than their conventional counterparts, and a significantly higher percentage of Fair Trade farmers reported an increase in their savings. Jaffee's study of 51 coffee producers in Oaxaca, Mexico, revealed that only $30.8 \%$ of Fair Trade members were indebted, compared to $41 \%$ of conventional producers. The average 
loan size for Fair Trade producers was small, at 2,345 pesos compared to 3,525 pesos for loans for conventional producers. Fair Trade producers were also less likely to need financing for the current harvest: $32 \%$ of Fair Trade had taken a loan in the last harvest, compared to $83 \%$ of conventional farmers. The author concludes that the level and timing of their coffee payment appear to give Fair Trade members greater liquidity and lower dependence on credit (Jaffee 2009). These results, while informative, should be taken with caution, given the small sample size and potential selection bias affecting the simple comparison of means. Without controlling for differences between Fair Trade certified farmers and non-certified farmers, it is not clear if the greater access to credit for Fair Trade producers is due to Fair Trade or to the pre-existing differences that are correlated with access to credit.

Another strand of the literature accounts for selection bias and shows that Fair Trade producers have better assets, higher rates of savings, and higher levels of animal stocks and perceive their land as having high renting value (Ruben and Zuniga 2011; Fort and Ruben 2009a and 200b and 2009b; Zuniga-Arias and Saenz-Segura 2009) than their non-certified counterparts. Indeed, the book by Ruben et al. on the impact of Fair Trade found that Fair Trade producers consistently dedicate higher relative expenditure shares to long-term investment in household durables, home improvements, and education (Ruben 2009). Consistent with these findings, Barham et al. (2011) found that investment in schooling is more prevalent and far greater in magnitude than are investments in coffee. Investments in migration are less frequent but involve much higher commitments. Investment in coffee was quite low; the average annual investment in the coffee farm was US\$47, with a range from $\$ 25$ to $\$ 93$ among regions, calculated as the market wage times the household labor time spent on farm improvement activities (Barham et al. 2011). 
Finally, even though market access is cited frequently as one of the primary reasons for farmers to undertake Fair Trade certification, the evidence is scant. The percentage of output sold at Fair Trade rates was not systemically reported, but references indicate amounts between $13 \%$ and $100 \%$ of output. In one comparison of different certification types, Fair Trade certification had the lowest proportion of output sold at certified prices, at $60 \%$ of total volume sold at the higher rates (Mendez et al. 2010). Most studies indicated that cooperatives' contracts with Fair Trade buyers were made at least for one year, and often for longer, although in two cases, Fair Trade prices were paid through spot markets. Interestingly, there is evidence that suggests that the timing of buyer payments to producers was important in the decision to sell to Fair Trade markets. For example, Bacon (2005) found in a study of 228 Nicaraguan farmers that cooperatives pay farmers in stages, first as credit for the harvest, second when farmers bring the wet coffee to the dry processing facility, and third when actual prices were calculated. On average, Fair Trade-certified farmers waited about one month and a half before receiving full payment, while Organic certified farmers waited more than two months. The late payment was owing to delays in receipt of payment from overseas buyers and the relatively small size of cooperatives that prevented them from having the capital on hand to advance payment to producers.

\section{IV.5 Labor, Education and Health}

Producers of less labor intensive products such as coffee are considered by the FLO as small-scale producers if farm work is mostly done by family members; thus, the absence of studies on Fair Trade's impact on coffee farm labor is not surprising. However, the FLO stipulates that plantations can hire labor and must pay them legal minimum wage. There is a 
dearth of studies on Fair Trade's impact on labor, with the exception of a study on labor in the East African flower industry (Riisgaard 2009) and a study of banana workers in Ghana (Ruben and van Schendel 2009). The latter finds that, although the salaries of Fair Trade workers are lower, they work fewer hours and obtain better fringe benefits. Despite high Fair Trade price premiums and regional labor shortages, the absence of wage premiums might be explained by socially embedded labor market rigidities (Ruben and Zuniga 2011).

In addition to wages and employment, there might be other channels through which Fair Trade might affect labor outcomes. Fair Trade certification implies that the cooperative is maintaining minimum working conditions, such as freedom from discrimination, freedom of labor, compliance with minimum wages laws, and prevention of employment of children below the age of 15 or the age defined by local law, whichever is higher. Given that an important fraction of children in developing countries are working in family farms (Edmonds and Pavnick 2005), the FLO allows children under the age of 15 to work if they work after school or during holidays, the type of work is not dangerous or exploitative, and the number of work hours of supervised by their parents.

Based on a simple neoclassical model of household time allocation, the number of children engaged in farm work could decrease if household income rises due to Fair Trade certification. At the same time, however, child labor could be positively correlated with Fair Trade certification due to an increase in the demand for family labor, as has been suggested by Kruger (2007) in her study of the child labor response to the temporary surge in coffee prices during the 1990s in Brazil. At the macro level, Baland and Duprez (2009) argues that the higher demand for labelled goods might have a displacement effect in developing countries whereby adult workers replace children in the export sector while children replace adults in the domestic 
sector. Anecdotal evidence suggests that in rural Nicaragua working conditions on Fair Trade coffee farms do not significantly differ from informal working conditions (Valkila and Nygren 2010), but not much information is provided in the literature quantifying other labor outcomes in coffee-growing regions.

It should be noted that there might be some additional labor effects if the farmer is engaged in Organic production where hired labor is not regulated. Anecdotal evidence has shown that Fair Trade-Organic farmers pay more in some regions per quantity of product picked, but Organic produce can be more time consuming to pick because of low yields, and so Fair TradeOrganic may provide few benefits to hired labor (Valkila 2009).

In regards to health outcomes, the evidence, although minimal, suggests a positive correlation. Arnould et al. (2009) developed an index of family health based on incidence of disease and found that, although Fair Trade producers did not have a significantly different incidence of disease, farmers who had participated in Fair Trade networks for at least 6 years had a significantly lower disease incidence. Membership in Fair Trade cooperatives also significantly increased the likelihood of receiving medical treatment when needed. Mendez et al. (2010) found that a significantly higher percentage of certified households reported having difficulty meeting food needs than non-certified groups, potentially because of higher production costs and the timing of Fair Trade payments beyond the hungry season between April and August. On the contrary, Jaffee (2009) found that two-thirds of Fair Trade farmers self-report lower food shortages and higher dietary quality than non-certified farmers.

Similarly, other papers have found a positive correlation with Fair Trade certification and education outcomes. For example, it has been shown that Fair Trade farmers' children are more likely to be currently studying at school (Arnould et al. 2009), and Fair Trade farmers spend 
more on education (Zuniga-Arias and Saenz-Segura 2009). These correlations are informative but should be taken with caution.

\section{Conclusions}

This paper has examined the empirical evidence on the impact of Fair Trade on the welfare of small-scale producers in developing countries as well as relevant theoretical and methodological concerns. In our view, Fair Trade has the potential to improve the welfare of producers in developing countries, and although there has been considerable progress in both the theoretical and empirical research on the impacts of Fair Trade in the past decade, there remain areas where more research is needed.

The weight of the cross-sectional mean differences favors a positive impact on producers' prices and income, but our review highlights the importance of limited market access and changes in productivity. For market access, Fair Trade premiums are earned on a fraction of producers' output owing to limited world demand, and as such, the gross amount of those premiums per producer is relatively small. An important issue is that the percentage of output which actually goes to Fair Trade-Organic markets has a significant impact on whether certification improves profits. Certification affects costs across all production, but premiums (if they exist) are only given for output that reaches Fair Trade markets. The percentage of output sold as Fair Trade is affected by the cooperative size, saturation of world Fair Trade markets, quality of the produce, and cooperative rules for spreading losses across sales categories.

In terms of yields, Fair Trade rules do not necessarily encourage producers to change production practices to improve productivity and thus revenues. To the extent that Fair Trade supports the creation of cooperatives and those cooperatives become competent delivery bodies 
for technical advice, however, Fair Trade can encourage productivity enhancements. Indeed, we can understand conversion to Fair Trade production as the adoption of a technology for the intensification of production through marketing and productivity enhancements (Valkila 2009; Bolwig et al 2009), particularly when conversion occurs from a baseline of low input use.

Methodological challenges are persistent in the empirical literature on Fair Trade. Few studies have the financial or temporal resources to develop panel data sets that track producers before and after certification. The controversy continues over how to address selection bias and choose the counterfactual. Difficulties in measuring field-level costs and yields are endemic to agricultural economics. Insofar as many Fair Trade producers are also organic, the investigation into how to measure costs, including family labor costs, leads to dramatically different findings. The literature is consistent in suggesting that conversion to Fair Trade-Organic production increases labor needs. Nonetheless, the increased income from Fair Trade could increase outmigration, making conversion to Fair Trade more difficult given the shortage of labor. At the same time, the scheme, particularly when used with plantation crops, can yield positive wage externalities throughout the region. There is scope for further research to systemically analyze these labor trends. 


\section{References}

Arnould, Eric J., Alejandro Plastina, and Dwayne Ball. 2009. "Does fair trade deliver on its core value proposition? Effects on income, educational attainment, and health in three countries." Journal of Public Policy \& Marketing 28 (2): 186-201.

Bacon, Christopher. 2005. "Confronting the coffee crisis: Can fair trade, organic, and specialty coffees reduce small-scale farmer vulnerability in northern Nicaragua?" World Development 33 (3): 497-511.

Bacon, Christopher. 2010. "A spot of coffee in crisis Nicaraguan smallholder cooperatives, fair trade networks, and gendered empowerment." Latin American Perspectives 37 (2): 50-71.

Baland, Jean-Marie and Cédric Duprez. 2009 "Are labels effective against child labor?" Journal of Public Economics, 93(11-12):1125-1130

Barham, Bradford L., Mercedez Callenes, Seth Gitter, Jessa Lewis, and Jeremy Weber. 2011. "Fair Trade/Organic coffee, rural livelihoods, and the "agrarian question": Southern Mexican coffee families in transition." World Development 39 (1): 134-45.

Barham, Bradford L., and Jeremy G. Weber. 2012. "The economic sustainability of certified coffee: Recent evidence from Mexico and Peru." World Development 40 (6): 1269-79.

Baumann, Florian, Matthias Oschinski, and Nikolai Staehler. 2012. "On the effects of fair trade on the welfare of the poor." Journal of International Development 24: S159-72.

Becchetti, Leonardo, and Giuseppina Gianfreda. 2010. "Does consumption heal producers? The effect of fair trade on marginalised producers' health in Kenya." Cahiers Agricultures 19 (1): 23-27.

Becchetti, Leonardo, Stefano Castriota, and Nazaria Solferino. 2011. "Development projects and life satisfaction: An impact study on fair trade handicraft producers." Journal of Happiness Studies 12 (1): 115-38.

Beuchelt, Tina D., and Manfred Zeller. 2011. "Profits and poverty: Certification's troubled link for Nicaragua's organic and fairtrade coffee producers." Ecological Economics 70 (7): 131624.

Bezencon, Valery. 2011. "Producers and the fair trade distribution systems: What are the benefits and problems?" Sustainable Development 19 (1): 60-70.

Blackman, Allen, and Jorge Rivera. 2011. "Producer-level benefits of sustainability certification." Conservation Biology 25 (6): 1176-85.

Blackmore, Emma, James Keeley, Rhiannon Pyburn, Ellen Mangus, Lu Chen, and Qiao Yuhui. 2012. Pro-poor certification: Assessing the benefits of sustainability certification for smallscale farmers in Asia. London: International Institute for Environment and Development (IIED).

Blowfield, Michael E., and Catherine Dolan. 2010. "Fairtrade facts and fancies: What Kenyan fairtrade tea tells us about business' role as development agent." Journal of Business Ethics 93: 143-62.

Bolwig, Simon, Peter Gibbon, and Sam Jones. 2009. "The economics of smallholder organic contract farming in tropical Africa." World Development 37 (6): 1094-104.

Breimer, Maarten, and de Vaal, Albert. 2011. "The effects of fair trade when productivity differences matter". Radboud U Nijmegen for ETSG meetings.

Calo, Muriel, and Timothy A. Wise. 2005. Revaluing peasant coffee production: Organic and fair trade markets in Mexico. Medford, USA: Global Development and Environment Institute, Tufts University. 
De Janvry, Alain, Craig McIntosh, and Elisabeth Sadoulet. 2011. Fair trade and free entry: The dissipation of producer benefits in a disequilibrium market. Working Paper. (April).

Dragusanu, Raluca, and Nathan Nunn. 2013. "The Impact of Fair Trade Certification: Evidence from Coffee Producers in Costa Rica," Mimeo, Harvard University

Dragusanu, Raluca, Daniele Giovannucci and Nathan Nunn. 2013. "The Economics of Fair Trade" Mimeo, Harvard University. First Version: September 2013.

Edmonds, Eric and Nina Pavcnik. 2005 "Child Labor in the Global Economy," Journal of Economic Perspectives, 18(1): 199- 220.

FINE. 2001. "Fair Trade Definition and Principles." Accessed August 122012.

FLO-CERT, 2011. "Fee System Small Producer Organization: Explanatory Document. Effective as of: 01.01.2013," Mimeo.

FLO. 2011 "Fairtrade Standard for Small Producer Organizations" Mimeo.

FLO. 2012 "Monitoring the Scope and Benefits of Fairtrade", Mimeo, Fourth edition.

Fort, Ricardo and Ruerd Ruben. 2009a. "The impact of Fair Trade on banana producers in Northern Peru." In The impact of fair trade, edited by Ruerd Ruben, 49-73. Wageningen, Netherlands: Wageningen Academic Publishers.

Fort, Ricardo, and Ruerd Ruben. 2009b. "The impact of Fair Trade Certification on coffee producers in Peru." In The impact of fair trade, edited by Ruerd Ruben, 75-98. Wageningen, Netherlands: Wageningen Academic Publishers.

Geiger-Oneto, Stephanie, and Eric J. Arnould. 2011. "Alternative trade organization and subjective quality of life: The case of Latin American coffee producers." Journal of Macromarketing 31 (3): 276-90.

Hayes, Mark. 2006. “On the efficiency of fair trade.” Review of Social Economy 64 (4): 447-468.

Hayes, Mark. 2008. "Fighting the tide: Alternative trade organizations in the era of global free trade - A comment." World Development 36 (12): 2953-2961.

Jaffee, Daniel. 2009. "'Better, but not great': the social and environmental benefits and limitations of Fair Trade for indigenous coffee producers in Oaxaca, Mexico." In The impact of fair trade, edited by Ruerd Ruben, 195-222. Wageningen, Netherlands: Wageningen Academic Publishers.

Kruger, Diana. 2007. "Coffee production effects on child labor and schooling in rural Brazil," Journal of Development Economics, 82(2):448-463

Leclair, Mark. 2002. "Fighting the tide: Alternative trade organizations in the era of global free trade." World Development 30 (6): 949-958.

Leclair, Mark. 2008. "Fighting the tide: Alternative trade organizations in the era of global free trade - A reply." World Development 36 (12): 2962-2965.

Makita, Rie. 2012. "Fair trade certification: The case of tea plantation workers in India." Development Policy Review 30 (1): 87-107.

Maseland, Robbert and Albert de Vaal. 2009. "Looking beyond the cooperative: Fair Trade and the income distribution." In The impact of fair trade, edited by Ruerd Ruben, 223-237. Wageningen, Netherlands: Wageningen Academic Publishers.

Mendez, V. Ernesto, Christopher M. Bacon, Meryl Olson, Seth Petchers, Doribel Herrador, Cecilia Carranza, Laura Trujillo, Carlos Guadarrama-Zugasti, Antonio Cordon, and Angel Mendoza. 2010. "Effects of fair trade and organic certifications on small-scale coffee farmer households in Central America and Mexico." Renewable Agriculture and Food Systems 25 (3): $236-51$. 
Nelson, Valerie, and Barry Pound. 2009. The Last Ten Years: A Comprehensive Review of the Literature on the Impact of Fairtrade. Greenwich: Natural Resources Institute.

Raynolds, Laura T., Murray, Dougla, and Taylor, Peter Leigh. 2004. "Fair Trade Coffee: Building Producer Capacity Via Global Networks." Journal of International Development 16 (8): 1109-1121.

Richardson, Martin, and Stahler, Frank. 2007. Fair Trade. Canberra: Australian National University Working Paper.

Riisgaard, Lone. 2009. "Global value chains, labor organization and private social standards: Lessons from east African cut flower industries." World Development 37 (2) : 326-40.

Ronchi, Loraine. 2002. The impact of fairtrade on producers and their organisations: A case study with coocafe in Costa Rica. University of Sussex Poverty Research Unit Working Paper, 11.

Ronchi, Loraine 2006. "Fairtrade' and market failures in agricultural commodity markets." World Bank Working Paper WPS4011.

Ruben, Ruerd, Luud Clercx, Dario Cepeda and Thomas de Hoop. 2009. "Fair Trade impact of banana production in El Guabo Association, Ecuador: a production function analysis." In The impact of fair trade, edited by Ruerd Ruben, 155-167. Wageningen, Netherlands: Wageningen Academic Publishers.

Ruben, Ruerd, ed. 2009. The Impact of Fair Trade. Wageningen, Netherlands: Wageningen Academic Publishers.

Ruben, Ruerd, and Guillermo Zuniga. 2011. "How standards compete: Comparative impact of coffee certification schemes in northern Nicaragua." Supply Chain Management-an International Journal 16 (2): 98-109.

Ruben, Ruerd, and Lucie van Schendel. 2009. "The impact of Fair Trade in banana plantations in Ghana: income, ownership and livelihoods of banana workers." In The impact of fair trade, edited by Ruerd Ruben, 137-153.Wageningen, Netherlands: Wageningen Academic Publishers.

Saenz-Segura, Fernando, and Guillermo Zuniga-Arias. 2009. "Assessment of the effect of Fair Trade on smallholder producers in Costa Rica: a comparative study in the coffee sector." In The impact of fair trade, edited by Ruerd Ruben, 117-135. Wageningen, Netherlands: Wageningen Academic Publishers.

Sick, Deborah. 2008. "Coffee, farming families, and fair trade in Costa Rica - new markets, same old problems?" Latin American Research Review. 43 (3): 193-208.

Smith, Erin, and William M. Loker. 2012. ""We know our worth": Lessons from a fair trade coffee cooperative in Honduras." Human Organization 71 (1): 87-98.

Vagneron, Isabelle and Solveig Roquigny, 2010. "What do we really know about the impact of fair trade? A synthesis", Paris: PFCE.

Valkila, Joni. 2009. "Fair trade organic coffee production in Nicaragua - sustainable development or a poverty trap?" Ecological Economics 68 (12): 3018-3025.

Valkila, Joni, and Anja Nygren. 2010. "Impacts of fair trade certification on coffee farmers, cooperatives, and laborers in Nicaragua." Agriculture and Human Values 27 (3): 321-333.

Weber, Jeremy G. 2011. "How much more do growers receive for fair trade-organic coffee?" Food Policy 36 (5): 678-685.

Zuniga-Arias, Guillermo, and Fernando Saenz-Segura. 2009. "The impact of Fair Trade in banana production of Costa Rica." In The impact of fair trade, edited by Ruerd Ruben, 99116. Wageningen, Netherlands: Wageningen Academic Publishers. 


\section{NOTES}

${ }^{i}$ We acknowledge that Fair Trade can affect other levels of actors, including cooperatives, communities, and states, and not just individual producers. This analysis, however, is beyond the scope of the paper, which is limited to producers' welfare. This topic reflects the focus of the literature and the objectives of the movement.

${ }_{i i}$ Our review includes peer-reviewed articles as well as books, working papers, literature reports, and dissertations. Papers were filtered out according to several criteria: those which focused on the consumer side of the market, the governance of Fair Trade and environmental and gender impacts were outside the scope of the study.

iii In 2013, producer organizations are paid a floor price of USD 1.40 per pound for Fair Trade certified washed Arabica and USD 1.35 for unwashed Arabica, or the market price (if higher). 